УДК 7.03

DOI: $10.22162 / 2500-1523-2020-2-302-314$

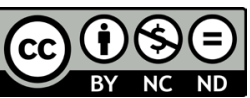

\title{
Выставка изобразительного искусства, посвященная 500-летию эпоса «Джангар»: первые профессиональные художники Калмыкии
}

\section{Светлана Гарриевна Батырева ${ }^{1}$}

${ }^{1}$ Калмыцкий научный центр РАН (д. 8, ул. им. И. К. Илишкина, 358000 Элиста, Российская Федерация) доктор искусствоведения, ведущий научный сотрудник (iD) 0000-0003-4268-0705. E-mail: sargerel@mail.ru

\author{
(C) КалмНЦ РАН, 2020
}

(C) Батырева С. Г., 2020

Аннотация. В статье рассматривается процесс становления профессионального изобразительного искусства в Калмыкии в 1930-е гг. Целью и задачами исследования являются воссоздание процесса сложения национальной школы, определение содержания и локальных особенностей искусства как части советской художественной культуры. Проблемой исследования является утрата большей части произведений довоенного изобразительного искусства Калмыкии в период Великой Отечественной войны и депортации народа (1943-1956). Материаль и методы. Материалом для исследования послужили произведения первых профессиональных художников Калмыкии И. Нусхаева, Л. Очирова, Р. Богославского и др., вдохновленных эпическим наследием и реалиями социалистического строительства. В работе применяется историко-культурный подход, определивший обращение к источникам (архивным материалам, свидетельствам очевидцев, сохранившимся произведениям и исследованиям); охарактеризована довоенная жизнь республики, обусловленная интеграцией в пространство культуры социализма. Результаты. Выявлено и рассмотрено центральное событие этого времени - подготовка и проведение художественной выставки, посвященной 500-летию калмыцкого героического эпоса «Джангар» в 1940 г. Выводы. Наследие народа обусловило локальное своеобразие формирования изобразительного искусства, основополагающее значение в этом процессе имели традиции русского реалистического искусства, представленные произведениями В. А. Фаворского и его коллег, посвященными республике и культуре народа.

Ключевые слова: искусство Калмыкии, традиции, социалистический реализм, эпос, выставки, художники

Благодарность. Исследованиепроведено в рамках государственной субсидии — проект «Комплексное исследование процессов общественно-политического и культурного развития народов Юга России» (номер госрегистрации: АААА-А19-119011490038-5). Для цитирования: Батырева С. Г. Выставка изобразительного искусства, посвященная 500-летию эпоса «Джангар»: первые профессиональные художники Калмыкии // Монголоведение. 2020. Т. 12. № 2. С. 302-314. DOI: 10.22162/2500-1523-2020-2-302-314 
UDC 7.03

DOI: $10.22162 / 2500-1523-2020-2-302-314$

\title{
Celebrating the 500 ${ }^{\text {th }}$ Anniversary of the Jangar Epic: Jubilee Exhibition of Kalmykia's First Professional Artists
}

\author{
Svetlana G. Batyreva ${ }^{1}$ \\ ${ }^{1}$ Kalmyk Scientific Center of the RAS (8, Ilishkin St., Elista 358000, Russian Federation) \\ Dr. Sc. (Art Studies), Leading Research Associate \\ iD) 0000-0003-4268-0705.E-mail: sargerel@mail.ru
}

(C) KalmSC RAS, 2020

(C) Batyreva S. G., 2020

\begin{abstract}
The article examines the emergence of Kalmykia's professional arts activities in the 1930s. Goals. It seeks to review formation stages of the ethnic school, determine its essentials and local features as part of Soviet artistic culture. In this regard, a fundamental research problem is that the vast majority of local pre-war visual arts works had been lost during the Great Patriotic War and Kalmyk deportation (1943-1956). Materials and Methods. Considered are works of Kalmykia's first professional artists - such as I. Nuskhaev, L. Ochirov, R. Bogoslavsky, etc. - inspired by epic heritage and realia of Socialist construction. The study employs a historical-and-cultural approach which determines the use of sources (archival papers, eyewitness reports, available pictorial works and studies); characterizes the pre-war life of the republic and its integration into Socialist cultural environment. Results. The paper reveals a central event of the era, examines the preparation and arrangements of the 1940 jubilee exhibition to celebrate 500 years of the Kalmyk heroic epic of Jangar. Conclusions. Cultural heritage proved most essential to the formation of Soviet Kalmykia's pictorial arts trend, central to the latter being traditions of Russian realistic art represented by ethnos-related works of V. Favorsky and his colleagues.
\end{abstract}

Keywords: Kalmyk arts, traditions, Socialist realism, epic, exhibitions, artists

Acknowledgements: The reported study was funded by government subsidy — project name 'Socio-Political and Cultural Development of South Russia's Peoples: Comprehensive Studies in Respective Processes' (state reg. no. AAAA-A19-119011490038-5)

For citation: Batyreva S. G. Celebrating the $500^{\text {th }}$ Anniversary of the Jangar Epic: Jubilee Exhibition of Kalmykia's First Professional Artists. Mongolian Studies (Elista). 2020. Vol. 12. No. 2. Pp. 302-314. (In Russ.) DOI: 10.22162/2500-1523-2020-2-302-314

\section{Введение}

Изобразительное искусство 30-х - начала 40-х гг. ХХ в. представляет собой в целом малоизученную область художественной культуры Калмыкии. В период Великой Отечественной войны и последовавшей в 1943-1956 гг. депортации калмыцкого народа были утрачены почти все произведения довоенного искусства. Источники по данной теме представляют собой сравнительно небольшой ряд архивных материалов [НА РК. Ф. Р.-131. Оп. 1; Калмыцкий театр 1972]. Среди исследовательских трудов: каталог выставки к 500-летию эпоса «Джангар» [Каталог выставки 1940], статья В. А. Фаворского «Как я работал над „Джангаром“» [Фаворский 1940: 20-25], труды об изобразительном искусстве Калмыкии И. И. Трошина [Трошин 1965; Трошин 1970], монографии 
С. М. Червонной «Живопись автономных республик РСФСР» и Л. В. Яковлевой «Художники Калмыцкой АССР» [Червонная 1978: 136-146; Яковлева 1972], каталог «Восток в творчестве В. А. Фаворского» [Восток в творчестве 1982: 7-15], труды И. Г. Ковалева [Фаворский в Калмыкии 1988; Ковалев 2019] и С. Г. Батыревой [Батырева 1990: 23-38; Батырева 2009: 538-540; Батырева 2014: 19-28], альбом «Художники Калмыкии» [Художники Калмыкии 2009]. Дополняет исследования издание «Мир эпоса» [Мир эпоса 1992], куда вошли воспоминания графика В. А. Фаворского, переводчика С. И. Липкина, а также статьи искусствоведа Е. Б. Муриной и составителя В. З. Церенова [Мир эпоса 1992: 58-94, 95-100, 107-114, 6-57]. За исключением свидетельств очевидцев и архивных данных большая часть источников об этом периоде истории калмыцкого искусства имеет опосредованный характер.

Культуре 1930-х - начала 1940-х гг. посвящена глава «От народного творчества и самодеятельности к зарождению реалистического профессионального мастерства» в «Очерках изобразительного искусства Калмыкии» И. И. Трошина [Трошин 1970: 63-77], где автор излагает известные ему сведения о довоенном искусстве Калмыкии. Не упоминая депортацию калмыков, сопровождаемую «жестокими утратами культуры в годы выселения в Сибирь» [Мурина 1992: 110], он говорит далее о развитии искусства в республике в послевоенный период с 1957 по 1960-е гг. [Трошин 1970: 78-120].

С. М. Червонная, допуская неточности в переложении известных материалов, освещает «первый этап развития советской живописи Калмыкии» [Червонная 1978: 137-141], Л. В. Яковлева кратко очерчивает этот период [Яковлева 1972: 3-4]. Заметим, что художественное осмысление темы депортации появляется в калмыцком искусстве лишь на рубеже 80-90-х гг. ХХ в. [Бадмаева 1994].

Обозревая источники, выявляем характерную особенность довоенного периода, а именно специфическую художественную среду, характеризующуюся совместной деятельностью местных и московских художников. Привнесение художественно-пластических средств русского реализма в живопись и графику (посредством и образования) оказало влияние на творчество калмыцких авторов. Этим следует определять главные предпосылки становления национальной школы, приобретающей оформившиеся черты в конце XX в. Цель исследования - воссоздание процесса сложения национальной школы, определение содержания и локальных особенностей искусства как части советской художественной культуры. Основное внимание уделяется первым профессиональным художникам Калмыкии, принявшим участие в выставке, посвященной 500-летию эпоса «Джангар».

Историко-культурное изучение взаимовлияния традиций обусловлено вниманием к проблемам сохранения и возрождения национального искусства, что актуально в отсутствии специальных работ по данной теме и значимо в контексте глобализации современной культуры.

\section{Иллюстрации к эпосу «Джангар» (1940 г.)}

Становление профессионального искусства Калмыкии происходило в условиях антирелигиозного культштурма в 1930-е гг., борьбы за ликвидацию безграмотности населения, развития культуры и образования республики. Описывая процесс приобщения народа к новой художественной культуре, 


\section{Этнология}

И. И. Трошин указывает: «Большую роль в подготовке к выставке и в росте национальных кадров Калмыкии сыграло Постановление правления СХ СССР от 21 февраля 1940» [Трошин 1970: 67], призванное содействовать подготовке юбилейной выставки, посвященной 500-летию народного эпоса «Джангар», и изобразительному искусству, во многом «самодеятельному» вследствие «малочисленности состава профессионалов» [Трошин 1970: 66-76]. Исследователь дал характеристику состояния искусства, с которой нельзя не согласиться, но необходимо дополнить, уточнив. Живое бытие эпического наследия народа наполняло духовную жизнь Калмыкии 1930-х гг. Об этом делятся воспоминаниями очевидцы, отмечавшие, что эпос «Джангар» знают все жители Калмыкии [Мир эпоса 1992: 61, 95-99].

Заметим, эпическая струя в изобразительном искусстве Калмыкии жива до сих пор, явственно ощущается в фольклорных тенденциях современного художественного процесса. Эпос и художник в глубоких и проникновенных взаимоотношениях формируют образно-стилевые поиски в искусстве [Батырева 2009: 549-550]. Начало этому было положено в 30-е гг. ХХ в., период формирования живописи и графики, скульптуры и сценографии, прикладного творчества в специфике выразительных средств профессионального изобразительного искусства.

В творческой атмосфере довоенной Калмыкии, готовящейся отметить 500-летие героического эпоса, собирается материал для создания иллюстраций к его юбилейному изданию. Книжное оформление эпоса «Джангар» В. А. Фаворского и его творческой группы — явление, рассматриваемое в советском искусствознании как средоточие кросскультурных взаимовлияний традиций в изобразительном искусстве [Восток в творчестве 1982: 10-12; Мир эпоса 1992: 107-114; Батырева 2014: 20, 24, 26].

Перевод эпического наследия на язык изобразительного искусства всегда актуален и сложен, требует высокого профессионализма авторов. Важно умение чутко уловить содержание и передать этнический колорит образов фольклора специфическими средствами книги.

Во взаимосвязи эпического повествования и сюжетов изображения авторами трактован текст в структуре довоенного издания эпоса, оформляемого шрифтом, титулами, заставками и концовками, орнаментом. Особая роль отдана орнаменту, в нем живут мироощущение и ритм номадической культуры, необходимые в создании ее художественного образа в искусстве. Иллюстрирование калмыцкого эпоса В. А. Фаворский, народный художник СССР, называет счастливым периодом своей творческой жизни. Находясь в эвакуации в Самарканде в 1942 г., он пишет: «...работаю над картиной... Тема - праздник в Калмыкии, ну как бы песнь о милых мне калмыках, об их красоте и своеобразном изяществе... работаю с большим удовольствием...» [Мир эпоса 1992: 58, 103].

Многофигурное полотно появилось по впечатлениям от джигитовки на Олимпиаде самодеятельного искусства. Красочные моменты народного праздника с центральной сценой рубки лозы художник мастерски обобщил, создав запоминающийся образ Калмыкии. Это живописное признание в любви ныне входит в собрание Национального музея РК им. Н. Н. Пальмова, как и ряд графических работ к оформлению издания эпоса «Джангар» 1958 г. [Джангар 1958], замещающих утраты 1940 г. 
В поездках по Калмыкии, знакомстве с народом и его наследием происходило творческое осмысление своеобразной культуры. Живое ощущение довоенной республики несут произведения В. А. и Н. В. Фаворских, Г. А. Ечеистова и Л. И. Аронова, сегодня зримо восполняющие тринадцатилетнюю брешь депортации в отражении художественной культуры народа. В высоком поэтическом строе предстает калмыцкое наследие, прочувствованное и переданное в «Джангариаде». Обозначаем этим словом не только иллюстративный ряд оформления довоенного издания, восстановленного в 1958 году, но и множество эскизов, рисунков, набросков, орнаментальных выкладок, ныне входящих в собрание Государственного музея изобразительных искусств имени А. С. Пушкина и частное собрание семьи Фаворских-Шаховских.

В большой папке с надписью «Калмыкия» бережно хранится собранное в знаменательной поездке В. А. Фаворского «в народ», о чем художник делится впечатлениями в статье «Как я работал над „Джангаром“» [Фаворский 1940: 20-25].

Обобщая этот материал, график И. Д. Шаховской, внук художника, и публицист В. 3. Церенов подготовили издание «Мир эпоса» [Мир эпоса 1992] к 550-летию калмыцкого эпоса «Джангар». В подготовке празднования принимала участие и дочь художника М. В. Фаворская, художник-керамист, член всесоюзной юбилейной комиссии по проведению юбилея в 1990 г. В эстафете культурных связей нитью преемственности восстанавливается целостность искусства, связывая воедино традиции, приобщающие к наследию.

Основополагающим в художественном процессе видим народное творчество, генерирующее пространство калмыцкой культуры 30-х гг. XX в. Участниками Олимпиады самодеятельного искусства в 1935 г. были мастера Э. М. Шараев, Б. Молоканова и Н. Саргинова, П. И. Емчегирова, резчики по дереву и рукодельницы-вышивальщицы. В экспозиции первой республиканской художественной выставки 1937 г. в Элисте была представлена живопись и графика И. С. Нусхаева, Л. Э. Очирова, мастеров прикладного искусства и самодеятельных художников. В произведениях превалировали тематические композиции на историко-революционные и хозяйственные сюжеты, что отвечало требованиям социалистического содержания искусства в указанный временной период [Батырева 2014: 20-21].

Каталог «Юбилейной выставки, посвященной 500-летию великого эпоса калмыцкого народа ,Джангар“»

В русле подготовки к празднованию 500-летнего юбилея эпоса «Джангар» в 1939-1940 гг. появляется ряд значительных произведений калмыцких художников. Документом раннего этапа формирования изобразительного искусства Калмыкии является сохранившийся каталог «Юбилейной выставки, посвященной 500-летию великого эпоса калмыцкого народа „Джангар“». Духом эпического наследия - «генофонда» истории и культуры калмыцкого народа проникнуто это издание, выпущенное в 1940 г. Управлением по делам искусств при Совнаркоме Калмыцкой АССР, Оргкомитетом Союза Советских Художников Калмыцкой АССР, Выставочным комитетом [Каталог 1940], его автором-составителем и редактором является художник И. С. Нусхаев. 


\section{Этнология}

Материал каталога позволяет выделить основные тематические направления произведений. Образы богатырей, воплощающих национальные идеалы духовности, изображение их подвигов во имя страны Бумбы и народа, органично дополненные портретами сказителей Анджуки Козаева, Давы Шавалиева, Мукебюна Басангова, Эренджена Самтонова, в устах которых эпос продолжал жить, — основная, эпическая, канва экспозиции. Параллельно ей было представлено современное бытие Калмыкии, показан интернациональный состав творческой интеллигенции в образах артистки ансамбля М. Саргиновой, художника В. А. Фаворского, режиссера Калмыцкого театра Е. Н. Цатуряна.

Отвечая духу времени, зримо присутствовала тема социалистического труда в портретах стахановцев («Учетчик Ц. Манджиев», портретах бригадиров Д. Эльзятиева, Г. Мукебенова, У. Цебекова), строителей дороги «Элиста - Дивное». Идеологическая составляющая прослеживается в образах, созданных в работах «Помполиты Лиджи-Гаряева и Шеркешова», «Политрук С. Д. Гаряева», «Агитатор Басаева». Лирической нотой звучит степной пейзаж в живописных и графических набросках: «Утро на трассе», «Старая роща», «Вечером», «Перед дождем», «Кибитка».

\section{И. С. Нусхаев: жизнь и деятельность}

До настоящего времени не сохранились полотна талантливого живописца Ивана Нусхаева, названного С. Липкиным учеником В. А. Фаворского [Мир эпоса 1992: 97], произведения калмыцких художников Лиджи Очирова, Сергея Хазыкова, Родиона Богославского, Николая Фатова. Трагичной была судьба некоторых из них: в 1942 г. по доносу были арестованы органами НКВД Л. Э. Очиров, сосланный на поселение в Казахстан, после чего сведений о нем не поступало, и И. С. Нусхаев, умерший в тюрьме г. Магнитогорска [Художники Калмыкии 2009].

Имея художественное образование (Астраханский художественный техникум), Иван Сидорович Нусхаев (1910-1944(5?) обучался в Институте пролетарского изобразительного искусства в Ленинграде. В культурную жизнь Калмыкии вошел в 1934 г. История и наследие народа определили тематическое многообразие его живописи, впервые показанной на Олимпиаде 1935 г. В 1937 г. он - один из организаторов, членов жюри первой художественной выставки в Калмыкии [НА РК. Ф. Р-131. Оп. 1. Ед. хр. 94. Л. 29-32].

С 1939 г. И. Нусхаев работал в Управлении по делам искусств СНК Калмыцкой АССР [НА РК. Ф. Р-131. Оп. 1. Ед. хр. 508. Л. 35], являлся председателем республиканского оргкомитета Союза художников СССР. Эрудированный, знающий историю и культуру народа, необыкновенно работоспособный, художник обладал незаурядными способностями организатора.

Большое значение для изучения истории изобразительного искусства довоенной Калмыкии имеет его вступительная статья к каталогу выставки 1940 г. Предваряя ее социалистическими лозунгами, И. С. Нусхаев упоминает имена художников-калмыков А. Е. Егорова, профессора Санкт-Петербургской академии художеств, его сына Е. А. Егорова, а также Н. Н. Аберды и Ф. И. Калмыка, придворного живописца герцога Баденского, указывая на высокий творческий потенциал народа. В качестве примера он приводит имена известных мастеров старокалмыцкой живописи Шарлузунга Монцаева и Ендона Бадмаева, творцов 
«прекрасных, оригинальных и самобытных произведений, вполне отличительных от бурят-монгольского, китайского письма» [Каталог 1940: 3]. Последнее характеризует Ивана Нусхаева как художника, знающего иконографию буддизма, увлеченного стилевыми поисками в искусстве религиозной живописи, что, предполагаем, могло быть основанием доноса в органы НКВД.

Период 1933-1934 гг. И. С. Нусхаев определяет временем появления первых профессиональных калмыцких художников, к которым относит и себя, указывая, что «несмотря на многочисленные препоны, молодые художники собственными усилиями и энергией организовали в 1937 г. первую республиканскую выставку живописи, скульптуры, графики, послужившую фундаментом для организации творческого Союза Советских Художников Калмыцкой АССР». Немногочислен состав вновь образованного творческого союза: 7 членов и 1 кандидат в члены CX (5 живописцев, архитектор, искусствовед и резчик по дереву) [Каталог 1940: 4].

Автор высоко оценивает произведения московских графиков В. А. и Н. В. Фаворских, Г. А. Ечеистова и живописца Л. И. Аронова, значимо поднявших профессиональный уровень юбилейной художественной выставки в Калмыкии в 1940 г.

Иллюстрирование эпоса основывалось на работе авторов «в поле». Открытие степи, народа и его самобытной культуры несут зарисовки, сделанные на натуре, превалирующие у Г. А. Ечеистова («Артистка Ляля Русакова», «Вид Элисты», «Мостик», «В степи»). Их дополняет портретная и пейзажная живопись Л. И. Аронова: «Засл. артистка Калм. АССР Улан Лиджиева» ${ }^{1}$, «Джангарчи Дава Шавалиев», «Старушка-калмычка», «На строительстве дороги „Элиста-Дивное“»».

Графический цикл о Калмыкии, ее истории, людях и природе объединяет поэтический образ юной калмычки, стоящей у дверей юрты, открытых в необозримую ширь Степи... Рисунок В. А. Фаворского символичен в понимании работы над эпосом во фронтисписах к песням о подвигах Хонгра, Санала, Савра Тяжелорукого, Мингйана - первого красавца Вселенной, выполненных темперой на левкасе. Иллюстрация ко вступлению воспроизводит многоярусную композицию страны Бумбы. Найденное плоскостное построение пространства органично продолжено в композиции «Пир Джангара» Н. В. Фаворского - сына Владимира Фаворского, автора сюжетов «Три мальчугана-богатыря», «Сражение Хонгра Алого Льва и Аля Монхля». В цветных фронтисписах емко выражено время и пространство этнической культуры. Образ старого Шикширги - ключ к пониманию картины мира номадов, представленной в иллюстрациях на юбилейной выставке.

Сохранение образной памяти предков - задачу, стоявшую перед художниками, И. С. Нусхаев связывает с необходимостью «учиться у мастеров русского искусства». Произведения В. А. Фаворского послужили, по его мнению, «толчком в творческом развитии калмыцких художников» в процессе «создания изобразительного искусства нашей республики». Автор подчеркивает необходимость поддержки со стороны Управления по делам искусств, Оргкомитета Союза художников СССР. Судя по высказываниям И. С. Нусхаева, первого художника

\footnotetext{
${ }^{1}$ Так в издании.
} 


\section{Этнология}

Калмыкии, развитие искусства им понимается во взаимодействии традиций «русского и западно-европейского искусства», «прошлого и настоящего калмыцкого народа, его любовного и кропотливого изучения» [Каталог 1940: 4].

Желанием работать во благо культуры народа одухотворены поиски автора в живописи и графике, театрально-декорационном и монументально-декоративном искусстве. Из обширного наследия И. С. Нусхаева сохранились лишь живописные наброски на тему «Пушкин в Калмыкии» (Национальный музей Республики Калмыкии им. Н. Н. Пальмова) как уникальное свидетельство его творчества. На этапе «сбора материала» живо передана композиция, изображающая поэта в интерьере калмыцкой кибитки, прочувствован в работе на пленэре колорит произведений. Тема диалога культур занимала воображение художника, он мечтал о создании большого живописного полотна.

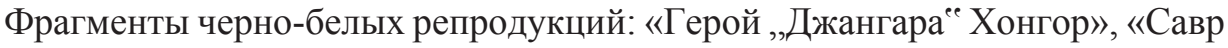
Тяжелорукий», «Джангарчи Дава Шавалиев» [Художники Калмыкии 2009] представляют живопись И. С. Нусхаева, отмеченную свободным владением построения формы, приемами уверенной линейной композиции. Запоминается подчеркнутой динамикой образ богатыря Савра в полном боевом вооружении. Мастерской штриховкой вылеплен этнический тип в погрудных изображениях богатыря Хонгра Алого Льва и сказителя Д. Шавалиева. На выставке 1940 г. многожанровое и разноплановое творчество И. С. Нусхаева было представлено 65 работами.

Профессиональную станковую живопись автора дополняют поиски в монументально-декоративном искусстве. По инициативе И. С. Нусхаева здание кинотеатра «Родина» в г. Элисте (проект архитектора В. Калмыкова) к открытию юбилейной выставки было украшено монументальной живописью. Декор 1939 г. представлял собой монументально-декоративные росписи с орнаментальными мотивами, размещенные в верхней части здания; ими были расписаны главный вход, южный фасад и интерьер малого зала. После ремонта здания в середине 1970-х гг. фрески довоенного времени были утрачены [Кинотеатр-юбиляр 1994: 3].

\section{Работы первых художников Калмыкии на юбилейной выставке}

В разделе народного декоративно-прикладного искусства юбилейной выставки демонстрировалось панно вышивальщиц Б. Молокановой и Н. Саргиновой на эпический сюжет, выполненные по эскизу И. С. Нусхаева.

В экспозиции также была представлена скульптура «Джангар» резчика по дереву Э. М. Шараева, участника первой республиканской художественной выставки 1937 г. Как указывает И. И. Трошин, Эрдни Менкеевич Шараев, народный мастер из колхоза «Ленинский путь» Троицкого улуса, был впоследствии принят в члены СХ СССР. В подготовке к торжествам 500-летия героического эпоса «Джангар» им были вырезаны сюжетные композиции: «Хонгор на коне» и «Колхозный табун», образцы рельефной резьбы с растительными мотивами, а также образ В. И. Ленина. В традиционной обработке дерева были изготовлены бутафорные элементы декораций к юбилейному театрализованному представлению «Бумбин орн» [Трошин 1970: 68].

Неутомимый в творчестве И. С. Нусхаев пробовал себя в качестве художника-декоратора в совместной работе с Н. С. Фатовым по оформлению юбилейного 


\section{Монголоведение • Mongolian Studies • 2020 • T. 12 • № 2}

спектакля «Бумбин Орн». Ими были исполнены занавес, эскизы декораций «Дворец Джангара», «Ущелье», «Крепость в Болзатин Бор», а также эскизы костюмов Ага Шавдал, богатырей Хонгора и Мингйана, Алтана Цеджи, Савра и Санала. Знание и трепетное отношение к фольклору одухотворили красочное оформление спектакля «Бумбин Орн» [Калмыцкий театр 1972: 88, 122, 128 ].

В разработке эскизов декораций и костюмов к спектаклю «Бумбин Орн» принимал участие Дмитрий Вячеславович Сычев (1908-1996), впоследствии заслуженный деятель искусств Калмыцкой АССР, работавший в национальном театре со дня его основания в 1936 г. Профессионализм выпускника Кубанского художественно-педагогического техникума и школы-студии Мейерхольда в Москве был реализован в оформлении спектаклей русской и зарубежной классики в 1936-1938 гг. в театре, в который автор вернулся по восстановлении автономии Калмыкии.

Изучение народного орнамента позволило ему создать запоминающееся оформление спектакля по пьесе Б. Басангова «Чууче», постановок «Бумбин Орн» и «Случай, достойный удивления», иллюстраций к калмыцким сказкам в 1970-е гг. Известен созданный им в 1938 г. портретный цикл артистов довоенного периода; Б. Мемеева, У. Лиджиевой и других [Калмыцкое изобразительное 1990: 46-47; Батырева 2014: 77-78].

Пробовал свои силы в сценографии С. А. Хазыков (1912-1989), выпускник Московского архитектурного института, оформивший спектакль по пьесе К. Тренева «Любовь Яровая» в калмыцком театре, в живописи он обращался к теме «Пушкин в Калмыкии».

При поддержке Д. В. Сычева осваивал основы сценографии Л. Э. Очиров в работе над декорациями к «Оратории» и эскизами костюмов к некоторым спектаклям [Калмыцкий театр 1972: 88].

Активное участие художников И. С. Нусхаева, Н. С. Фатова, Д. В. Сычева, Л. Э. Очирова и С. А. Хазыкова в оформлении театральных постановок довоенного времени свидетельствует о бурном становлении театрально-декорационного искусства [Калмыцкий театр 1972; Трошин 1965: 26-27].

С театром и изобразительным искусством связано имя артиста Лиджи Эрдниевича Очирова (р. в 1914 г.), окончившего Калмыцкую драматическую школу в 1931 г. Навыки профессионального владения масляной живописью, а также графическими техниками гуаши, туши, акварели он получил в Саратовском художественном промтехникуме в 1931-1934 гг. В довоенном искусстве Калмыкии он был известен под творческим псевдонимом «Очаровский», в 1939 г. назначен первым директором организованной в это время Калмыцкой картинной галереи [Батырева 2014: 22].

Слывя натурой порывистой и романтичной, Лиджи Очиров тяготел к обобщению эпической тематики, создав живописные композиции «Джангар-полководец», «Богатыри Родины» и др. в самобытной трактовке образов. Историко-этнографический сюжет на юбилейной выставке был представлен его произведениями: «Калмыцкий хотон», «Кибитка», «Старый калмык», «Калмыцкая невеста», «Петр I на приеме у калмыцкого хана» [Художники Калмыкии 2009].

Открытием явился живописный «Автопортрет» Л. Э. Очирова, выполненный маслом в 1939 г., высоко оцененный В. А. Фаворским, председателем выставкома 


\section{Этнология}

юбилейной экспозиции 1940 г., и московскими коллегами. Голова художника дана в динамичном повороте справа налево, глаза пытливо устремлены на зрителя. Высокие скулы, твердый подбородок и плотно сжатые губы говорят о целеустремленном характере.

Входя в республиканский оргкомитет Союза художников, Л. Э. Очиров принимал активное участие в подготовке и проведении юбилейной экспозиции.

Значительное количество полотен принадлежало кисти преподавателя рисования школы № 1 г. Элисты Родиона Никандровича Богославского (1915-1998), окончившего Московский художественный техникум [Ковалев 2019]. Теме калмыцкого эпоса автор, впоследствии участник Великой Отечественной войны, посвятил композицию «Борьба Хонгора Алого Льва с Цаганом», отмеченную в отчетах московских художников, а также представил более 30 пейзажей («Вечер», «Старая роща», «На трассе», «Субботник на строительстве дороги «Элиста - Дивное», «На верблюде» и др.) и портретов («Сидящая девушка», «Мальчик с козой», «Красноармеец» и др.). Р. Н. Богославским были созданы тематические композиции «Орденоносец Гаряев среди детей», «Девушка-калмычка, записывающая народные песни» и «Золотошвеи». Довоенная Калмыкия, представленная в обстоятельном рассмотрении событий, характеризует вдумчивое отношение автора к изображаемой реальности.

Всего на выставке 1940 г. было представлено около 200 произведений живописи, графики, скульптуры и декоративно-прикладного искусства. Количество и качество произведений, прошедших отбор компетентной комиссии, свидетельствует о большой совместной и плодотворной работе художников. Описание ее приведено в отчетах Л. Аронова, Г. Ечеистова, Н. Аввакумова оргкомитету СХ СССР, указываемых И. И. Трошиным [Трошин 1970: 70].

Произведения «Собрание в колхозе», «Всеобуч», портреты колхозников и детей художницы П. И. Емчегировой (1907-1992), окончившей Астраханский художественно-педагогический техникум в 1935 г., не дошли до нашего времени. «Автопортрет» П. И. Емчегировой в калмыцком костюме (1940) хранится в Национальном музее Республики Калмыкия им. Н. Н. Пальмова. Помимо П. И. Емчегировой, первой художницы-калмычки, в коллектив художников Элисты входили В. Г. Лесной и Н. С. Фатов, Е. К. Амосова, Л. В. Братков и 3. И. Гогжаев, автор рисунков для газеты «Ленинский путь» на тему труда и нового быта Советской Калмыкии. Предполагаем, что отсутствие их произведений в юбилейной экспозиции и, соответственно, в каталоге выставки, можно объяснить взыскательным отбором выставкома во главе с В. А. Фаворским [Каталог 1940], призванного сформировать экспозицию из произведений профессионального уровня. Трудно переоценить роль В. А. Фаворского в развитии изобразительного искусства довоенной Калмыкии в целом и, в частности, в организации юбилейной выставки 1940 г.

В тесных культурных контактах были расширены границы творческой деятельности калмыцких и столичных художников. Искусство 1930-х гг. получало импульс к развитию через приобщение к эпическому наследию, отражая историю, быт и духовность народа. Насколько плодотворным был этот период, можно было судить по прошествии полувека. Цикл зарисовок «Калмыкия» В. А. Фаворского (более 150 произведений) по инициативе Калмыцкой госу- 
дарственной картинной галереи был представлен в 1990 г. в юбилейной художественной экспозиции «Калмыкия глазами В. А. Фаворского» (к 550-летию эпоса «Джангар»). Ее продолжением явилась выставка «Школа В. А. Фаворского» [Батырева 1990; Батырева 1991], представляющая реалистические основы русского изобразительного искусства в творчестве Г. А. Ечеистова, В. К. Федяевской, Т. С. Козулиной, Н. В. Константинова, восстановивших утраченные иллюстрации 1940 г. в издании калмыцкого эпоса «Джангар» 1958 г.

\section{Выводы}

Обобщая изложенный материал, приходим к следующим выводам:

- активная выставочная деятельность, пиком которой явилась подготовка юбилейной экспозиции к 500-летию эпоса «Джангар», дала мощный импульс к развитию профессионального изобразительного искусства Калмыкии, для которого характерен органичный синтез традиций;

- творчество первых художников-профессионалов, работавших в различных видах и жанрах, формировалось в обращении к традициям реализма, имевшим основополагающее значение в довоенный период;

- важной составляющей художественного процесса явилось мифопоэтическое мировидение народа, воплощенное в калмыцком героическом эпосе «Джангар». Выполняя миссию «самосознания культуры», обозначенную произведениями, эпическое наследие определило высокий эмоциональный строй художественной жизни;

- изобразительное искусство как этнокультурная доминанта художественного процесса развивалось в органичном синтезе с другими формами творческой активности этноса: музыки, театра и танца, исполнительского мастерства сказителей;

- строящей социализм, открытой в движении к новому 一 такой предстает довоенная республика, ее народ и культура в произведениях, документах и архивных сведениях о выставках и художниках.

\section{Источники}

НА РК — Национальный архив Республики Калмыкия. Ф. Р-131.

\section{Литература}

Бадмаева 1994 - Бадмаева A. А. Тема депортации в изобразительном искусстве Калмыкии: альбом. Элиста: Кавказская здравница, 1994. С. 1-3.

Батырева 2014 - Батырева С. Г. Изобразительное искусство Калмыкии XX века (1957-2000 гг.). Элиста: КИГИ РАН, 2014. 226 с.

Батырева 2009 - Батырева С. Г. Изобразительное искусство // История Калмыкии с древнейших времен до наших дней: в 3 т. Элиста: ИД «Герел», 2009. Т. 3. С. 538-553.

Батырева 1991 - Батырева С. Г. Школа В. А. Фаворского // Известия Калмыкии. 1991. 25 сент. C. 4.

Батырева 1990 - Батырева С. Г. Калмыкия глазами В. А. Фаворского // Советская Калмыкия. 1990. 22 авг. С.4.

Фаворский в Калмыкии 1988 - В. А. Фаворский в Калмыкии: альбом / Сост. и авт. вступ. ст. И. Г. Ковалев. Элиста: Калмыцкая государственная картинная галерея, 1988. 12 репродукций.

Восток в творчестве 1982 - Восток в творчестве В. А. Фаворского. Сб. материалов и каталог выставки. М.: Советский художник, 1982. 38 с. 


\section{Этнология}

Джангар 1958 - Джангар. Калмыцкий народный эпос. М.: Худож. лит. 1958. 361 с.

Калмыцкое изобразительное 1990 - Калмыцкое изобразительное искусство. Тематический лекторий. Элиста: Калмыцкая государственная картинная галерея, 1990. 99 с.

Ковалев 2019 - Ковалев И. Г. Солдат, художник, учитель Р. Н. Богославский. 1915-1998. Ставрополь: Студия графики, 2019. 128 с.

Мир эпоса 1992 - Мир эпоса. О работе В. А. Фаворского над «Джангаром» и его поездке в Калмыкию / сост. В. З. Церенов. Элиста: Калм. кн. изд-во. 1992. 127 с., ил.

Мурина 1992 - Мурина Е. Б. Живое ощущение эпоса // Мир эпоса: о работе В. А. Фаворского над «Джангаром» и его поездке в Калмыкию. Элиста: Калм. кн. изд-во. 1992. С. $107-114$.

Калмыцкий театр 1972 - Калмыцкий театр (1927-1967): материалы и документы / Сост. Д. В. Сычев; вступ. ст. В. Д. Пюрвеева. Элиста: КНИИЯЛИ, 1972. 377 с.

Каталог выставки 1940 - Юбилейная выставка, посвященная 500-летию великого эпоса калмыцкого народа «Джангар»: живопись, скульптура, графика. Каталог выставки / Управ. по делам искусств при Совнаркоме Калм. АССР. Оргкомитет Союза Советских Художников Калм. АССР. Выставочный комитет / ред. и авт. вступ. ст. И. Нусхаев. Элиста: Тип. № 1 НКМП, 1940. 16 с.

Кинотеатр-юбиляр 1994 - Кинотеатр-юбиляр // Советская Калмыкия, 1994. 16 июня. C. 3.

Трошин 1965 - Трошин И. И. Изобразительное искусство Калмыцкой АССР. Элиста: Калм. кн. изд-во, 1965. 82 с., ил.

Трошин 1970 - Трошин И. И. Очерки изобразительного искусства Калмыкии. Волгоград: Волгоградская правда, 1970. 121 с., ил.

Фаворский 1940 - Фаворский В. А. Как я работал над «Джангаром» // Детская литература. М.: Молодая гвардия, 1940, № 5. С. 20-25.

Художники Калмыкии 2009 - Художники Калмыкии. Элиста: ЗАОр «НПП «Джангар», 2009. 160 с.(ил.)

Червонная 1978 - Червонная С. М. Живопись автономных республик РСФСР (19171977). М.: Искусство, Науч.-исслед. ин-т теории и истории изобразительных искусств АХ СССР. 1978. 208 с., ил.

Яковлева 1972 - Яковлева Л. В. Художники Калмыцкой АССР. Л.: Художник РСФСР. 1972. 22 с., 17 л., с ил.

\section{Sources}

National Archive of the Republic of Kalmykia. Coll. P-131. (In Russ.)

\section{References}

Artists of Kalmykia. Elista: Dzhangar, 2009. 160 p. (In Russ.)

Badmaeva A. A. Pictorial arts of Kalmykia: the deportation theme. In: The Album. Elista: Kavkazskaya Zdravnitsa, 1994. Pp. 1-3. (In Russ.)

Batyreva S. G. $20^{\text {th }}$-Century Pictorial Arts of Kalmykia: 1957-2000. Elista: Kalmyk Humanities Research Institute of RAS, 2014. 226 p. (In Russ.)

Batyreva S. G. Kalmykia in the eyes of V. Favorsky: jubilee exhibition of V. Favorsky's Jangar-related works. Sovetskaya Kalmykiya. 1990, August 22. P. 4. (In Russ.)

Batyreva S. G. Pictorial arts. In: History of Kalmykia: From Earliest Times to the Present Days. In 3 vols. Elista: Gerel, 2009. Vol. 3. Pp. 538-553. (In Russ.)

Batyreva S. G. The V. Favorsky school. Izvestiya Kalmykii. 1991, September 25. P. 4. (In Russ.) Chervonnaya S. M. Autonomous Republics of the RSFSR: Pictorial Art, 1917-1977. Moscow: Iskusstvo, Pictorial Arts Theory and History Research Institute (Soviet Academy of Arts), 1978. 208 p. (In Russ.)

Cinema theatre celebrates its anniversary. Sovetskaya Kalmykiya. 1994, June 16. P. 3. (In Russ.) Favorsky V. A. How I worked on the Jangar. Detskaya literatura. 1940. No. 5. Pp. 20-25. (In Russ.) 
Kalmyk Pictorial Arts: Thematic Lecture Hall. Elista: Kalmyk State Picture Gallery, 1990. 99 p. (In Russ.)

Kovalev I. G. (comp.) V. Favorsky in Kalmykia: Art Book. I. G. Kovalev (foreword). Elista: Kalmyk State Picture Gallery, 1988. 12 pictorial reproductions.

Kovalev I. G. R. Bogoslavsky (1915-1998): Soldier, Artist, Teacher. Stavropol: Studiya Grafiki, 2019. 128 p. (In Russ.)

Murina E. B. A living sense of the epic. In: The World of Epic: Jangar-Related Works of V. Favorsky and His Journey to Kalmykia Revisited. Elista: Kalmyk Book Publ., 1992. Pp. 107-114. (In Russ.)

Nuskhaev I. (ed.) Jubilee Exhibition to Celebrate 500 Years of the Jangar Epic: Pictorial, Plastic and Graphic Arts. Exhibition catalogue. Council of People's Commissars of Kalmyk ASSR, etc. I. Nuskhaev (foreword). Elista: Print. House No. 1 NKMP, 1940. 16 p. (In Russ.)

Orient in V. Favorsky's Works. Coll. materials and exhibition catalogue. Moscow: Sovetskiy Khudozhnik, 1982. 38 p. (In Russ.)

Sychev D. V. (comp.) Kalmyk Theatre: 1927-1967. Coll. materials and documents. V. D. Pyurveev (foreword). Elista: Kalmyk Research Institute of Language, Literature and History, 1972. 377 p. (In Russ.)

The Jangar: a Kalmyk Heroic Epic. Moscow: Khudozhestvennaya Literatura. 1958. 361 p. (In Russ.)

Troshin I. I. Essays on Kalmykia's Pictorial Arts. Volgograd: Volgogradskaya Pravda, 1970. 121 p. (In Russ.)

Troshin I. I. Pictorial Arts of the Kalmyk ASSR. Elista: Kalmyk Book Publ., 1965. 82 p. (In Russ.)

Tserenov V. Z. The World of Epic: Jangar-Related Works of V. Favorsky and His Journey to Kalmykia Revisited. Elista: Kalmyk Book Publ., 1992. 127 p. (In Russ.)

Yakovleva L. V. Artists of the Kalmyk ASSR. Leningrad: Khudozhnik RSFSR, 1972. $22+$ 17 p. (In Russ.) 